\title{
Notes on taxonomy of Erysimum (Erysimeae, Cruciferae) of Russia and adjacent states. II. Middle Asian purple- and orange-flowered species
}

\author{
D. A. German \\ South-Siberian Botanical Garden, Altai State University, Lenin Ave., 61, Barnaul, 656049, Russia \\ E-mail: oreoloma@rambler.ru; ORCIDiD:0000-0001-7951-1644
}

Keywords: botanical nomenclature, Brassicaceae, Kazakhstan, Kyrgyzstan, synonymy, Tajikistan, taxonomic revision, typification, Uzbekistan, wallflower.

Summary. Results of taxonomic revision of Middle Asian violet- and orange-flowered wallflowers are presented. Five (vs. eight as traditionally considered) species are recognised. Thus, A. Polatschek's four-species concept introduced in 2010 is generally supported in terms of lower species diversity of the group in question, though nomenclature is updated in various details including the newly proposed assignment of E. jodonyx to synonymy of E. samarkandicum. Lectotypes are designated for the names E. cyaneum, E. epikeimenum, E. franchetii, E. purpureum var. turkestanicum, E. samarkandicum, E. tianschanicum and E. violascens var. tschimganicum; typification of E. franchetii established on the taxonomically heterogenous material is done in agreement with its existing usage as a synonym of E. samarkandicum (not E. violascens). Redundancy of lectotypification of E. alaicum for which the holotype is extant is demonstrated. Further aspects of systematics, nomenclature, morphology and geography of the treated species are briefly discussed as well.

\section{Заметки по систематике рода Erysimum (Erysimeae, Cruciferae) России и сопредельных стран. II. Среднеазиатские фиолетово- и оранжевоцветковые виды}

\author{
Д. А. Герман \\ Южно-Сибирский ботанический сад, Алтайский государственный университет, \\ просп. Ленина, 61, г. Барнаул, 656049, Россия
}

Ключевые слова: ботаническая номенклатура, желтушник, Казахстан, Киргизия, синонимика, Таджикистан, таксономическая ревизия, типификация, Узбекистан, Brassicaceae.

Аннотация. Представлены результаты таксономической ревизии среднеазиатских оранжево- и фиолетовоцветковых представителей рода Erysimum. В целом подтверждено опубликованное в 2010 г. мнение А. Полячека о меньшем (5) числе соответствущих видов, нежели считалось ранее (8, а согласно Полячеку - 4), однако предложенная им синонимика частично пересмотрена, включая пополнение таковой E. samarkandicum названием E. jodonyx (syn. nov.). Для E. cyaneum, E. epikeimenum, E. franchetii, E. purpureum var. turkestanicum, E. samarkandicum, E. tianschanicum и E. violascens var. tschimganicum обозначены лектотипы; дизруптивная типификация основанного на гетеротипном материале E. franchetii закрепила текущее его понимание в качестве синонима E. samarkandicum (а не E. violascens). Показана безосновательность выбора лектотипа для E. alaicum ввиду наличия голотипа. Кратко обсуждены прочие аспекты систематики, номенклатуры, морфологии и географии рассмотренных видов. 
The present communication continues the series of publications (German, 2012, 2014) focusing on the systematics of wallflowers of Russia and adjacent countries (the former USSR). Here, the species with orange and/or violet flowers (with all hints) occuring in the Middle Asia (including South Kazakhstan) are considered. Within the outlined macroregion, the area in question is the center of diversity of orange- and violet-flowered members of Erysimum L., where five species, as presently delimited, occur out of eight known from Russia and adjacent states.

According to the available phylogenetic data (Abdelaziz et al., 2014; Moazzeni et al., 2014b), violet- and orange-flowered wallflowers do not form a monophyletic group. Nonetheless, relevant species share not only such a noticeable morphological peculiarity, but also some taxonomic problems why their joint consideration seems reasonable and justified.

The history of systematics of the discussed species is relatively short. In XIX century relevant gatherings were usually misidentified (as, e. g., Hesperis hookeri Ledeb. [=E. pallasii Pursh], E. purpureum Auch ex J. Gay, E. cheiranthus var. subincanum (C. A. Mey.) Regel [= E. flavum (Georgi) Bobrov s. 1.], E. cheiranthus var. subviride (Ledeb.) Regel [三E. ledebourii D. A. German]) or stood without identification. Noteworthy, as evidenced by E. Regel's annotation "An spec. nova floribus rubicundis?" of one of A. Regel's gatherings of E. cyaneum M. Pop., some ideas of non-equality of the Middle Asian plants to any known species apparently occurred but were not published. As a result, the only attempt to stress the specificity of Middle Asian plants taxonomically was the description by M. A. Franchet (1883) of E. purpureum var. turkestanicum Franch. subsequently synonimised with E. samarkandicum M. Pop. In XX century the situation had changed considerably, and within a three-decades period, from 1924 to 1955 , ten binomials referring to all five species accepted here have been validated. M. G. Popov $(1924,1925,1935)$ contributed most significantly in revealing the taxonomic diversity of the considered group by discovering four species. Six additional names were published in subsequent years, but only one of them, E. alaicum Novopokr., turned out to belong to a previously unknown species while other five were then (including the present study) synonymised with the species established by Popov. Two (E. epikeimenum N. Busch and $E$. franchetii $\mathrm{N}$. Busch) were relegated to synonymy of E. samarkandicum by A. I. Vvedensky on labels yet in 1938, before their publication (Busch, 1939)
Настоящая заметка продолжает цикл (German, 2012, 2014) публикаций, посвящённых систематике рода желтушник России и сопредельных стран (в масштабах бывшего СССР). Объектом данного сообщения стали виды, обладающие оранжевыми или фиолетовыми (включая весь спектр оттенков) цветками и не выходящие (редко - слегка выходящие) в своём распространении за пределы Средней Азии (включая Южный Казахстан), где сконцентрировано большинство (5) из восьми оранжево- и фиолетовоцветковых представителей Erysimum L., произрастающих в пределах обозначенного макрорегиона.

Согласно филогенетическим данным (Abdelaziz et al., 2014; Moazzeni et al., 2014b), pacсматриваемая группа не является монофилетичной, однако, поскольку соответствующие виды объединяются не только столь ярким признаком, как окраска венчика, но и целым рядом общих таксономических вопросов, совместное их рассмотрение представляется оправданным.

Систематика обсуждаемых видов имеет сравнительно недолгую историю. В ХІХ в. все они определялись неправильно (например, как Hesperis hookeri Ledeb. [= E. pallasii Pursh], E. purpureum Auch ex J. Gay, E. cheiranthus var. subincanum (C. A. Mey.) Regel [= E. flavum (Georgi) Bobrov s. 1.], E. cheiranthus var. subviride (Ledeb.) Regel [三E. ledebourii D. A. German]) или просто оставались неопределёнными, хотя догадки о возможном наличии в Средней Азии новых видов имели место. Например, один из сборов А. Регеля E. cyaneum M. Рор. содержит такое предположение, высказанное на этикетке Э. Регелем: “An spec. nova floribus rubicundis?”. Однако единственной успешной попыткой того периода таксономически обозначить специфику среднеазиатского материала явилось описание М. А. Франше (Franchet, 1883) разновидности E. purpureum var. turkestanicum Franch., впоследствии синонимизированной с E. samarkandicum M. Рор. В XX в. ситуация коренным образом изменилась, и в период с 1924 по 1955 гг. было обнародовано 10 видовых названий, относящихся ко всем пяти принятым в настоящей работе таксонам этого ранга. Наиболее весомый вклад в познание видового разнообразия обсуждаемой группы внёс М. Г. Попов (Popov, 1924, 1925, 1935), установивший 4 вида. Из опубликованных впоследствии биномиалов только E. alaicum Novopokr. оказался применимым к не описанному ранее, пятому виду группы, тогда как остальные пять были впоследствии (в том числе в данной 
and later "officially" synonymised accordingly (Botschantzev, Vvedensky, 1955); this viewpoint was generally accepted since then. By contrast, remaining three binomials (E. chrysanthum Botsch. et Vved., E. jodonyx Botsch. et Vved. and E. nuratense M. Pop. ex Botsch. et Vved.) remained accepted by all authors until Polatschek's (2010) revision was issued presenting a radically novel approach, viz. accepting just four instead of eight species of purpleand orange-flowered Middle Asian Erysimum and assigning the above three names, along with E. croceum M. Pop., to synonymy of other species. Shortly after that this concept was questioned (German, 2012), but no detailed revision has been performed.

Erysimum is well-known as a taxonomically complex genus because of considerable diversity, presence of groups of closely related and variable species, parallel evolution of morphological features, etc. There are at least two phenomena that further complicate the systematics of purple- and orange-flowered members of the genus, viz. multiple options of petal colour development in some species and quite common colour change upon drying. For example, violet (of various intensity), orange, orange-red, orange-brown and rarely (Gaziev, 2016) white flowers may be found in E. cyaneum (incl. E. tianschanicum Polatschek). White florwers are reported by V. L. Komarov (1896) for normally purple-flowered E. purpureum var. turkestanicum, i. e. E. samarkandicum. In some other species (not occuring within Middle Asia) with normally violet or orange flowers, yellow-flowerd forms are registered (e. g., E. amurense Kitag.: Kitagawa, 1933; E. pallasii: Tolmatchew, 1930); the cases of changing the corolla colour during anthesis are also known such as turning yellow to yellow-violet (E. hezarense Moazzeni: Moazzeni et al., 2014a). As for the colour change during or as a result of drying, orange is rarely preserved in sicco, often mutating to yellow (E. alaicum, E. croceum, E. cyaneum), reddish-brown (E. cyaneum), white, greyish (not in Middle Asian taxa), or violet (E. cyaneum). Violet flowers usually keep original colour, though cases of its turning to reddish-brown (E. cyaneum) or yellow (E. cyaneum, E. samarkandicum) are also known. Besides, examples of uneven discoloration are not uncommon, e. g., when the claw remains purple and the blade partly or completely turns yellow ( $E$. $s a$ markandicum). This variability repeatedly became a reason of both redundant descriptions of taxa and establishing synonyms.

The present study aims at taxonomic revision of orange- and violet-flowered species of Erysimum работе) сведены в синонимы к предыдущим четырём видам. При этом два из них (E. epikeimenum N. Busch и E. franchetii N. Busch) были синонимизированы на этикетках А. И. Введенским ещё в 1938 г., то есть до обнародования их во «Флоре СССР» (Busch, 1939), а затем - и «официально» в обработке для «Флоры Узбекистана» (Botschantzev, Vvedensky, 1955), что впоследствии не подвергалось сомнению. Оставшиеся три названия (E. chrysanthum Botsch. et Vved., E. jodonyx Botsch. et Vved., E. nuratense M. Pop. ex Botsch. et Vved.), а также E. croceum M. Pop., напротив, оставались принятыми во всех работах вплоть до 2010 г., когда вышла обработка А. Полячека, предложившего радикальное изменение представления о видовом разнообразии рассматриваемой группы в сторону уменьшения (с 8 до 4). Впоследствии такой подход был частично подвергнут сомнению (German, 2012), но детальной ревизии при этом проведено не было.

Следует отметить, что обычные сложности систематики желтушников, обусловленные значительным видовым богатством рода, наличием групп близкородственных видов, параллелизмом в эволюции морфологических структур и др., для представителей Erysimum, обладающих фиолетовыми или оранжевыми цветками, дополняются ещё двумя обстоятельствами - наличием нескольких вариантов окраски цветков у некоторых видов и весьма обычным изменением цвета лепестков при высушивании. В частности, y E. cyaneum (incl. E. tianschanicum Polatschek) отмечены фиолетовые (различной интенсивности), оранжевые, оранжево-красные, оранжевокоричневые, а в редких случаях (Gaziev, 2016) белые цветки; об альбиносной форме у обычно фиолетовоцветкового E. purpureum var. turkestanicum, то есть E. samarkandicum, сообщал В. Л. Комаров (Komarov, 1896). Для некоторых видов (не встречающихся в рассматриваемом регионе) характерно наличие, наряду с обычной оранжево- или фиолетовоцветковой, также желтоцветковой формы (E. amurense Kitag.: Kitagawa, 1933; E. pallasii: Tolmatchew, 1930); известны и примеры изменения окраски венчика в процессе цветения, например, от жёлтой до жёлто-фиолетовой (E. hezarense Moazzeni: Moazzeni et al., 2014a). Что касается изменения окраски лепестков в гербарии, оранжевый цвет почти никогда не сохраняется, превращаясь в жёлтый (E. alaicum, E. croceum, E. cyaneum), красновато-коричневый (E. cyaneum), белый или сероватый (у среднеазиатских видов не отмечено), а иногда и в фиолето- 
occurring in the Middle Asian region in light of the sharply contrasting appproaches: a well-established in the second half of XX century "many-species" concept of Soviet authors and a "few-species" one presented by A. Polatschek in 2010. The work is based on materials of first of all LE and TASH, to a large extent also AA and FRU, to a lesser degree $\mathrm{E}$, MHA, MW, $\mathrm{P}$ and $\mathrm{W}$, and least of other mentioned herbaria. Results are presented below as a synopsis of accepted species accompanied with full synonymy, data on types and distribution (by countries) along with comments on their morphology and nomenclature. вый (E. cyaneum). Фиолетовые цветки чаще всего сохраняют цвет, но нередки и случаи его изменения в красновато-коричневый $(E$. cyaneum) или жёлтый (E. cyaneum, E. samarkandicum), причём выцветание может быть неравномерным, когда, например, ноготок сохраняет пурпурный оттенок, а пластинка частично или полностью желтеет (E. samarkandicum). Отмеченная вариабельность неоднократно становилась причиной как излишнего описания видов, так и незаслуженного сведения других в синонимы.

Целью настоящего исследования явилась таксономическая ревизия произрастающих в среднеазиатском регионе оранжево- и фиолетовоцветковых желтушников в свете резко контрастирующих концепций - устоявшейся в советской ботанической литературе второй половины XX в. «многовидовой» и «маловидовой», опубликованной А. Полячеком в 2010 г. Работы основана на материалах ряда гербариев, в первую очередь, LE и TASH, в значительной степени также AA и FRU, в меньшей - E, MHA, MW, Р и W, в минимальной - прочих упомянутых в статье. Результаты представлены в виде аннотированного конспекта с полной синонимикой, данными о типах и распространении (по странам), а также комментариями по морфологии и номенклатуре рассмотренных видов.

Erysimum alaicum Novopokr., 1955, Fl. Kirgizsk. SSR 6: 174.

По протологу / on the protologue: “Алай (верховья р. Катта-Карамук) [Alai (upper reaches of KattaKaramyk)]" (Shevchenko, 1955: 175).

Typus: [Киргизия, Ошская обл. / Kyrgyzstan, Osh Prov.]: “Кирг ССР, Чон-Алайский район. Субальпийский луг в верховьях р. Катта-Карамук. [fl.] 27 июля 1943 года. Ф. А. Тихомиров [Kirghisian SSR, Chon-Alai district. Subalpine meadow in upper reaches of Katta-Karamyk. 27 July 1943. F. A. Tikhomirov] / [Дополнительная этикетка И. В. Новопокровского / additional label by I. V. Novopokrovsky]: Petala 10-11 mm longa, lamina $5 \mathrm{~mm}$ lata, $\odot, ~ 24$ ? Erysimum alaicum sp. nova mihi. Ab affinis E. canescenti Roth differt: lamina petalorum latiore (lateobovata) aurantiaca, petalis minoribus, foliis integerrimis, viridibus. 28 XI 1943. Novopok[rovsky]" (FRU!, iso [fragm.] - TASH!).

Распространение / distribution: Киргизия, Таджикистан / Kyrgyzstan, Tajikistan.

1. Collector of the type has not been mentioned in the protologue; Botschantzev suggested that it could be N. A. Dessyatova because only her collection (19 VI 1913, no. 2022) - LE ([LE01140641 \& LE01140642]!) from the locus classicus is available in LE. He accordingly annotated one of the two relevant specimens [LE01140642] as "isotypus". Polatschek also recognized that specimen as the isotype (1988, in sched.) and later (Polatschek, 2010: 256, with wrongly indicated date "9. 5. 1913") designated it as the lectotype thus making a neotypifa-
1. Отсутствие в протологе информации о коллекторе и наличие в LE единственного сбора из дол. р. Катта-Карамук (Н. А. Десятова, 19 VI 1913, № 2022, 2 эКз. [LE01140641 \& LE01140642]!) дало основание В. П. Бочанцеву предположить, что E. alaicum основан именно на нём и подписать один из дублетов [LE01140642] как изотип. Точно так же данный образец был обозначен в 1988 г. А. Полячеком, а впоследствии (Polatschek, 2010: 256, с ошибочно указанной датой сбора «9. 5. 1913») обнародован им в качестве лектотипа; 
tion which is of no power since the original material is extant (Turland et al., 2018: Art. 19.9).

2. Original element (one complete plant mounted on a sheet and a glued preparation of several flowers) in FRU is treatable as holotype under ICN Art. 9.1(b) (Turland et al., 2018). Availability of the duplicate in TASH (upper part of inflorescence and cauline leaf in the envelope) annotated as "typus" and supplied with a label identical to that of the FRU specimen but handwritten by T. A. Adylov does not change the status of the latter since relevant fragment was definitely taken from the type while preparing Erysimum treatment for the "Conspectus..." (Adylov, 1974), i. e. after the validation of E. alaicum. Accordingly, TASH duplicate is recognized as the isotype (Turland et al., 2018: Art. 8.3, Ex. 8).

3 . The authorship of the name E. alaicum is generally considered to be "Novopokr. ex E. Nikit." (e. g., Adylov, 1974; Yunusov, 1978; Czerepanov, 1995; Polatschek, 2010; Lazkov, Sultanova, 2014; Koch et al., 2018; IPNI; POWO; WFO, 2021). However, first, the species in the protologue and throughout the account (incl. contents and "Explanation" page of relevant volume) is named "Erysimum alaicum Novopokr.". Second, Shevchenko (1955: 175) explicitly stated that: 1) initially the species was roughcasted by I. V. Novopokrovsky who mentioned its differences from $E$. canescens Roth on the abovecited additional label partly reproduced as follows: "lamina petalorum latiore aurantiaca, petalis minoribus, foliis integerrimis, viridibus"; and 2) the description was prepared from the herbarium specimen by E. V. Nikitina. Out of these two parts of the protologue, viz. brief Latin diagnosis and detailed Russian description, only the prior one matters nomenclaturally since the taxon was published after 1 January 1935 (Turland et al., 2018: Art. 39.1). As far as both the diagnosis and the name itself are clearly ascribed in the protologue to Novopokrovsky, he is the only author of E. alaicum (Turland et al., 2018: Art. 46.2).

4. The concept of E. alaicum has been considerably broadened by Polatschek $(2010,2011)$ who assigned to this speices the specimens of a perennial wallflower of E. flavum (Georgi) Bobrov affinity, widely distributed in Tian Shan and Pamir-Alai, previously known chiefly as E. humillimum [auct. non] (C. A. Mey.) N. Busch and subsequently described as E. kamelinii D. A. German (German, 2012). An examination of the specimens cited by Polatschek under the name E. alaicum (which, with a couple of exceptions, I managed to see and revise) demonstrated that only two of them (the one select- данный выбор, представляющий собой неотипификацию, не имеет номенклатурной силы ввиду существования оригинального материала (Turland et al., 2018: Art. 19.9).

2. Типовой образец E. alaicum, депонированный во FRU (смонтированное растение с подклеенным препаратом цветков), согласно статье 9.1(b) «Международного кодекса номнклатуры...» (МКН; Turland et al., 2018), должен считаться голотипом. Наличие в TASH дубликата (верхняя часть соцветия и стеблевой лист, хранящиеся в конвертике), снабжённого этикеткой, написанной Т. А. Адыловым (содержание идентично таковой бишкекского образца) и обозначенного им как «typus», не влечёт изменения номенклатурного статуса типа, поскольку очевидно, что ташкентский фрагмент был отделён от него в процессе обработки Erysimum для «Конспекта...» (Adylov, 1974), то есть после описания E. alaicum. Соответственно, хранящийся в TASH дублет является изотипом (Turland et al., 2018: Art. 8.3, Ex. 8).

3. Авторство E. alaicum обычно принимается как «Novopokr. ex E. Nikit.» (Adylov, 1974; Yunusov, 1978; Czerepanov, 1995; Polatschek, 2010; Lazkov, Sultanova, 2014; Koch et al., 2018; IPNI; POWO; WFO, 2021; etc.). Однако, согласно первоисточнику, где таксон назван «Erysimum alaicum Novopokr.» (как в тексте, так и в содержании и «Пояснениях»), он «Первоначально намечен как новый вид Новопокровским. На этикетке он указывает на отличие от E. canescens: lamina petalorum latiore aurantiaca, petalis minoribus, foliis integerrimis, viridibus. (Описание по гербарному образцу сделано Никитиной Е. В.)» (Shevchenko, 1955: 175). Таким образом, протолог включает краткий латинский диагноз и подробное описание на русском языке, из которых лишь первый элемент имеет значение для целей действительного обнародования таксона после 1 января 1935 г. (Turland et al., 2018: Art. 39.1). Поскольку и название, и диагноз E. alaicum однозначно приписаны Новопокровскому, он является единственным автором данного биномиала (Turland et al., 2018: Art. 46.2).

4. Понимание E. alaicum было существенным образом изменено А. Полячеком (Polatschek, $2010,2011)$ за счёт причисления к данному виду образцов многолетнего желтушника из родства E. flavum (Georgi) Bobrov, широко распространённого на Тянь-Шане и Памиро-Алае и ранее обычно называемого E. humillimum [auct. non] (C. A. Mey.) N. Busch, а впоследствии описанно- 
ed by him as the "lectotype" and the collection of S. I. Korshinsky made on 27 VI 1895 in the valley of Kel-Duk (LE!), mistranslated as "Katta-Karamyk") indeed belong to this species while others represent E. kamelinii. As a result, the data on both morphology and distribution of E. alaicum turned out to be seriously distorted. The problem was highlighted and clarified shortly after that (German, 2012), but the wrong information leaked into the literature and can be currently found, for example, in POWO. Therefore, it is appropriate to stress again that no reliable gatherings of E. alaicum are known from Afghanistan, China, Kazakhstan, Pakistan and Uzbekistan. The species is restricted to Kyrgyzstan and Tajikistan, in agreement with previous treatments (Shevchenko, 1955; Adylov, 1974; Yunusov, 1978) and revised material. Nearly all collections are from Tajikistan [predominantly Hissar-Darvaz where the species is relatively common (Yunusov, 1978); LE!] while within Kyrgyzstan only few gatherings are known, all from upper reaches of tributaries of Kyzyl-sy closest to Tajikistan, viz. Kel-Duk and Katta-Karamyk (Ok-Suu). By curious accident, locus classicus of E. alaicum is situated within this small area. Based on the available material, finding of the species outside Kyrgyzstan and Tajikistan is unlikely. го как E. kamelinii D. A. German (German, 2012). Как показал анализ образцов, приведённых Полячеком под названием E. alaicum, подавляющее большинство из которых удалось проверить, только два (выбранный им в качестве «лектотипа» и экземпляр С. И. Коржинского от 27 июня 1895 г. из дол. р. «Катта-Карамук», а в действительности - Кёль-Дук (LE!)) принадлежат к этому виду, остальные же представляют E. kamelinii. В результате этого данные о морфологии и распространении вида оказались сильно искажены и, несмотря на оперативное опровержение (German, 2012), проникли в ботаническую литературу (см., например, распространение, показанное для E. alaicum на ресурсе POWO). В связи с этим представляется уместным подчеркнуть ещё раз, что достоверные сборы данного вида из Афганистана, Казахстана, Китая, Пакистана и Узбекистана отсутствуют, и что он, в соответствии с предыдущими обработками (Shevchenko, 1955; Adylov, 1974; Yunusov, 1978), ограничен в своём распространении Таджикистаном, сборы откуда, особенно из Гиссаро-Дарваза, довольно многочисленны (Yunusov, 1978; LE!), и Киргизией, где вид произрастает на очень небольшой территории - лишь в верховьях ближайших к границе с Тажикистаном притоков р. Кызыл-су (Кёль-Дук и Катта-Карамук [= Катта-Карамык, Ок-Суу]), откуда и был описан. Исходя из имеющегося на данный момент материала, нахождение E. alaicum за пределами этих двух стран маловероятно.

Erysimum croceum M. Pop., 1935, Bull. Soc. Nat. Moscou. Sect. Biol., nouv. sér. 44 (3): 130.

По протологу / on the protologue: "Hab. in lapidosis et glareosis ad rivulum Almatinka minor, in regione abietina, 1500-2500 m fl. et fr, leg. M. G. Popov" (Popov, 1935: 130).

Lectotypus (Goloskokov, 1963: 21, “type”; Bajtenov, 1982: 6, “type”): [Казахстан, Алматинская обл. / Kazakhstan, Almaty Prov.]: “КазАССР. Р. М. Алматинка. Ручей Батарейка. Галечники. 21 VIII 1933. [fl.] М. Г. Попов [Kazakh ASSR. M[alaya] Almatinka. Batareika brook. On the gravel. 21 VIII 1933. M. G. Popov]" (AA!; isolecto - AA!; syn: M. G. Popov [fl.], 30 V 1933 - LE [LE01140643 - LE01140650]!; other original elements: N. I. Rubtzov [fr. mat.], 22 VI 1933 - AA!; N. I. Rubtzov [fl., fr. immat.], 25 VI 1933 - LE [LE01140651]!).

Распространение / distribution: Казахстан, Киргизия, Китай (Синьцзян) / Kazakhstan, Kyrgyzstan, China (Xinjiang).

1. A two-steps lectotype designation is accepted here based on the following considerations. Citing the gathering as the type, indicating the herbarium and mentioning "two specimens" by Goloskokov (1963) resulted in the initial choice which was subsequently narrowed to the single specimen by $\mathrm{Ba}-$ jtenov (1982) who also cited the "type" but specified "AA and one isotype". Both authors wrongly mentioned the collection year of the type gathering
1. Здесь принята двуступенчатая лектотипификация, осуществлённая В. П. Голоскоковым (Goloskokov, 1963) и М. С. Байтеновым (Bajtenov, 1982). В первом случае лектотипом («типом») был обозначен один сбор, хранящийся в одном гербарии и представленный двумя образцами («2 экз.»). Последующее цитирование данного сбора с уточнением «АА и 1 изотип» сузило данный выбор до конкретного образца. В обоих 
as 1938 due to ink discolouration on the label but this technical error to be corrected does not preclude valid typication (for details, see German, Veselova, 2011: 1381).

2. There is some uncertainty regarding the lectotype gathering of E. croceum. Both flowering and fruiting material collected by Popov are mentioned in the protologue and "fr." is indicated on the lectotype label by collector / species author himself which is well in agreement with the late (third dacade of August) collecting time. However, both his gatherings (the second one is: "Alma-Ata, M[alaya]. Almatinka, near Medeu, gravel bedstream. 30 V 1933. M. G. Popov") comprise plants in the beginning of flowering, occasionally with very first fruits and look indistinguishable from each other despite almost three months' difference in collecting dates. The reason of such a discrepancy is unclear. The only seen original element with ripe fruits and seeds is a specimen "KazASSR. Trans-Ili Alatau. Talus slope in 1/2 km from the building of the reserve. 22 VI 1933. N. I. Rubtzov". This specimen was not counted by German and Veselova (2011) but it clearly represents an uncited part of the original material along with another specimen of the same collector ("KazASSR. Trans-Ili Alatau. Almat. reserve. Stony floodplain of M. Almatinka near the building of the reserve. $25 \mathrm{VI}$ 1933. N. I. Rubtzov"), both bearing author's annotation "Erysimum croceum M. Pop. sp. n.".

3. Relegation of $E$. croceum to synonymy of $E$. virgatum Roth first proposed by Polatschek (2010) is apparently based on the superficial resemblance of these two undoubtedly closely related species in sicco. This viewpoint is now reproduced in some databases (POWO; WFO, 2021) but it is not supported morphologically (German, 2012) and E. croceum is generally accepted nowadays as a separate species (e. g., Kokoreva et al., 2010; Roldugin, 2014; Abidkulova et al., 2017; Baitulin et al., 2017).

4. Erysimum croceum has recently been recorded for the first time from China (Ya et al., 2018). случаях из-за выцветания чернил на этикетке год сбора указан неверно (1938), однако эта техническая ошибка не отменяет данной типификации (подробнее об этом - German, Veselova, 2011: 1381).

2. Существует некоторая неопределённость относительно типового сбора $E$. croceum. В протологе упомянут материал в фазе цветения и плодоношения, а на этикетке лектотипа присутствует авторская пометка «fr.», вполне соответствующая указанному позднему времени сбора (третья декада августа), но противоречащая актуальной фенофазе растений, которые, как и на втором сборе Попова («Р. М. Алматинка бл. Медеу, по гравийно-каменистому руслу ручья. $30 \mathrm{~V} 1933$. М. Г. Попов»), находятся в состоянии зацветания - первых плодов, и не отличимы от последних. Причина такого противоречия непонятна. Единственный изученный аутентичный экземпляр со зрелыми плодами - образец «КазАССР. Заилийский Алатау. Каменистая осыпь в $1 / 2$ км от зд. заповедника. 22 VI 1933. Н. И. Рубцов». Он не был учтён в работе по типам крестоцветных АA (German, Veselova, 2011), однако, несомненно, представляет часть первоначального материала, как и другой сбор того же коллектора («КазАССР. Заилийский Алатау. Алмат. заповедник. Каменистая пойма М. Алматинки бл. зд. заповедника. 25 VI 1933. Н. И. Рубцов»); оба подписаны автором вида как «Erysimum croceum M. Pop. sp. n.».

3. Отнесение E. croceum в синонимы к $E$. virgatum Roth, впервые предложенное Полячеком (Polatschek, 2010), несомненно, объясняется внешним сходством этих очевидно близкородственных видов in sicco. Этот подход отражён в некоторых базах данных (POWO; WFO, 2021), однако он не подтверждается морфологией (German, 2012), и E. croceum принимается в настоящее время подавляющим большинством авторов (Kokoreva et al., 2010; Roldugin, 2014; Abidkulova et al., 2017; Baitulin et al., 2017; etc.).

4. Erysimum croceum недавно был впервые найден в Китае (Ya et al., 2018).

Erysimum cyaneum M. Pop., 1924, Key P1. Envir. Tashkent: 157. EErysimum violascens var. tschimganicum M. Pop., 1925, Bull. Univ. As. Centr. 9, Suppl. (Sched. Herb. Fl. As. Med., 4): 25.

По протологу / on the protologue: "Встречается только в одном месте: Чимган, по каменистым склонам [Occurs in one locality only: Chimgan, on stony slopes]" (Popov, 1924: 157).

Lectotypus (hic designatus): [Узбекистан, Ташкентская обл. / Uzbekistan, Tashkent Prov.]: “Большой Чимган. 14 VIII 1922 [fl., fr. submat.]. Собр. Батуева, опр. М. Г. Попов [Bolshoy Chimgan. 14 VIII 1922. Coll. Batuyeva, det. M. G. Popov]” (TASH № 73317!; other original elements: О. А. Симонова [fl.], 1 VII 1922, № 358 - MHA!; П. Васильев [fl.], 8 VII 1920 - TASH № 9419!; id. [fl., fr. immat.], 15 VII 1920 - TASH № 9387!; Т. Баранова [fl., fr. immat.], VI [1]923 - TASH № 73318!; Г. А. Балабаев 
[alab., fl. prim.], 26 V 1916 - LE!, TASH № 73319!; possibly also: A. Regel [fl., fr. prim.], 20 Juni - 2 Juli 1881 - LE!).

Распространение / distribution: Киргизия, Узбекистан / Kyrgyzstan, Uzbekistan.

= Erysimum chrysanthum Botsch. et Vved., 1941, Not. Syst. Herb. Inst. Bot. Sect. Uzb. Acad. Sci. URSS 3: 11, nom. illeg. (Art. 53.1), non Pančić (1874). E Erysimum tianschanicum Polatschek, 1994, Phyton (Horn) 34 (2): 201. - Synonymised by Polatschek (2010: 204).

По протологу / on the protologue: "Турus: Западный Тянь-шань. Бассейн р. Чаткал. Верховья p. Сандалаш, котлов. басс. р. Ачик-таш. С-В склон сая вершины, перев. Мин-булак, $\mathrm{h}=2980$ м. 1938. VIII. 19 fl. et fr. jun. Пятаева и Момотов, 1222 (in Herb. Hort. Bot. Univer. As. Med. conservatur)" (Botschantzev, Vvedensky, 1941: 12).

Lectotypus (hic designatus): [Киргизия, Джалал-Абадская обл. / Kyrgyzstan, Jalal-Abad Prov.]: “Западный Тянь-Шань. Бассейн р. Чаткал. Верховья р. Сандалаш, котлов. басс. р. Ачик-таш. С.-В. склон сая вершины, перев. Мин-булак, $\mathrm{h}=2980$ м. 19 VIII 1938. [fl., fr. jun.] А. Пятаева и И. Момотов, № 1222 [Western Tian Shan. Chatkal basin. Upper reacher of Sandalash, basin of Achik-tash. NE slope of the sai at the summit, Min-bulak pass at elev. 2980 m. 19 VIII 1938. A. Pyatayeva \& I. Momotov 1222]" (TASH № 183964!; isolecto - TASH № 183965!).

1. Polatschek (2010) was the first to propose conspecificity of the orange-flowered E. tianschanicum with the lilac-fowered E. cyaneum, a viewpoint initially considered by me as doubtful (German, 2012). However, a study of additional material showed that indeed the alleged differences in plant height and petal size break down and, most important, flower colour is a variable character. Most valuable in this respect are quite numerous collections kept in FRU (predominantly by I. G. Sudnitsyna, N. V. Gorbunova and A. U. Ubukeyeva) with colour of flowers in vivo mentioned on labels that provides an opportunity of concluding the way it altered upon drying. Due to this advantage, it became obvious that lilac petal colour of herbarium specimens may correspond to both initially lilac and various shades of orange (purely orange, orangered, reddish-orange, orange-brownish), and the same is true for yellow and orange-brownish petal colour of dried plants. Noteworthy are collections consisting of a mixture of orange- and violetflowered plants such as, for example, the gathering of I. G. Sudnitsyna and N. V. Gorbunova from the locality Chon-Kashka-At (basin of Kara-Korum) dated 15 June 1966, where the flower colour of the single specimen with violet petals out of the total four is retained while the remaining three initially reddish-orange-flowered specimens are represented by plants with chromatic variants ranging from violet (though less dark compared to the previous plant) to yellow. Similar picture is illustrated by the collection made by L. R. Philippe et al. in lower reaches of Chandalash on 20 June 1999 comprising two specimens numbered 30681 (E [E00702666]!) and 30694 (E [E00711476]!). According to the
1. Синонимизация оранжевоцветкового E. tianschanicum с фиолетовоцветковым E. cyaneum, впервые предложенная А. Полячеком (Polatschek, 2010), представлялась мне ранее сомнительной (German, 2012), однако изучение дополнительного материала показало, что различия в размерах растений и длине лепестков на самом деле не выдерживаются, а их цвет является вариабельным признаком. Особую ценность в этом отношении представляют сборы (гл. обр. И. Г. Судницыной, Н. В. Горбуновой и А. У. Убукеевой), хранящиеся во FRU, на этикетках которых указан цвет лепестков in vivo, что даёт возможность судить о его изменении при высушивании. Бдагодаря этому удалось установить, что лиловый цвет лепестков на гербарных экземплярах может относиться как к изначально лиловому, так и к разным вариантам оранжевого (оранжевый, красновато-оранжевый, оранжевокрасный, оранжево-коричневый), и то же касается жёлтых и оранжевато-коричневых цветков сухих образцов. Заслуживают упомининия коллекции, включающие как лилово-, так и оранжевоцветковые растения, например, сбор И. Г. Судницыной и Н. В. Горбуновой от 15 июня 1966 г. из уроч. Чон-Кашка-Ат (басс. р. Кара-Корум), из которых единственный образец с фиолетовыми лепестками сохранил их природный цвет, а три с изначально красновато-оранжевыми представлены в сухом виде спектром вариантов от фиолетового (более бледного) до жёлтого. Сходную картину демонстрируют два образца, собранные в низовьях р. Сандалаш 20 июня 1999 г. Л. Р. Филиппом и коллегами - №№ 30681 (Е [Е00702666]!) и 30694 (Е [Е00711476]!). Соглас- 
labels, the first had in vivo orange and the second purple petals. In sicco, however, on both specimens some flowers are orange-brown (as on the lectotype of E. cyaneum) and others are violet. In all these cases no additional characters separating the plants with different petal colour have been revealed. Based on these evidences synonymising E. tianschanicum (but not E. jodonyx Botsch. et Vved. and E. epikeimenum N. Busch, see below) with E. cyaneum is reconsidered as justified and adopted here.

2. A report of E. cyaneum for Tajikistan (Polatschek, 2010) is not confirmed; it is based on erroneous treating E. epikeimenum conspecific with the prior by this author.

3. The need of choosing the lectotype of E. chrysanthum is based on the lack of indication of a number of the type specimen in the protologue coupled with the annotation of relevant duplicates by Botschantzev as "typus" (TASH № 183964) and “cotypus” (TASH № 183965) dated 27 XII 1947, six years after the species was described. This means that original designation of the type refers to the whole gathering and subsequent Botschantzev's clarification on the labels is an unpublished choice of the lectotype that is validated herein. но этикеткам, первый представлен растениями с оранжевыми, а второй - с пурпурными цветками; в сухом же состоянии на обоих образцах цветки частью оранжевато-коричневые (как на лектотипе $E$. cyaneum), а частью - фиолетовые. Во всех отмеченных случаях дополнительных морфологических различий между растениями с разным цветом лепестков не выявлено. На основании этого E. tianschanicum (но не E. jodonyx Botsch. et Vved. и E. epikeimenum N. Busch - см. ниже) принят здесь в качестве синонима E. cyaneum.

2. Показание E. cyaneum для Таджикистана (Polatschek, 2010) не подтверждается; оно основано на ошибочном отнесении к нему в синонимы E. epikeimenum данным автором.

3. Необходимость выбора лектотипа $E$. chrysanthum продиктована тем, что при описании номер образца указан не был, а составляющие типовой сбор дублеты были подписаны В. П. Бочанцевым как «typus» (TASH № 183964) и «cotypus» (TASH № 183965) только 27 декабря 1947 г., спустя шесть лет после описания вида. Таким образом, обозначение типа в протологе относится ко всему сбору, а последующее уточнение Бочанцева на этикетках фактически является неопубликованной лектотипификацией, формально закреплённой здесь.

Erysimum samarkandicum M. Pop., 1925, Bull. Univ. As. Centr. 9, Suppl. (Sched. Herb. Fl. As. Med., 4): 24, in nota.

По протологу / on the protologue: "Elle se rencontre seulement dans le bassin supérieur du fleuve Zeravchan" (Popov, 1925: 24).

Lectotypus (hic designatus): [Таджикистан, Согдийская обл. / Tajikistan, Sughd Prov.]: "Flora Seravschanica. Revat [fl., fr. immat.]. Alt. 5000 pd. 7 VI 1893. V. L. Komarov" (LE [LE01140656]!; элемент первоначального материала / original element: "Бассейн Зеравшана и Гиссарский хребет. Искандеровская вол. Самаркандской обл. [fl.] Г. А. Балабаев [Zerawschan basin and Gissar range, G. A. Balabayev], 1915” - TASH № 73286!; вероятный элемент первоначального материала / possible original element: "Flora Seravschanica. Farap (fl. Kaschka-daria) [fl.]. Alt. 6000 pd. 25 VI 1893. V. L. Komarov" LE [LE01140657]!).

Распространение / distribution: Таджикистан, Узбекистан / Tajikistan, Uzbekistan.

Original material for E. samarkandicum also includes the gathering of M. Capus on which the subsequent name is based, but it is not (no more since 1935) restricted to that element as long as the protologue includes both direct reference to E. purpureum var. turkestanicum and a concise diagnosis in French (differences from $E$. violascens). The choice provided by ICN Art. 6.13 is made in favour of the material studied by the author of the species. Two out of three above-cited specimens bear Popov's identifications: "Erysimum maracandicum M. Pop. (sp. n.)" (lectotype) and "Erysimum samarkandicum M.
Первоначальный материал по E. samarkandicum включает также сбор М. Капю, на котором основано следующее название, но (с 1935 г.) не ограничивается им, поскольку протолог содержит не только прямую ссылку на E. purpureum var. turkestanicum, но и краткий диагноз на французком (приведены отличия от E. violascens). Выбор, предоставляемый в данном случае статьёй 6.13 МКН, сделан в пользу материала, изученного автором вида. Из трёх приведённых выше образцов два снабжены авторскими определениями - «Erysimum maracandicum M. Pop. 
Pop." (TASH specimen); the gathering from Farap is not annotated by Popov but it cannot be excluded that it was also studied by him prior to the validation of the species name. The specimen from Revat is given preference in choosing the lectotype because 1) unpublished epithet "maracandicum" favours the suggestion that the annotation was made before the publication, when the species name was not yet finally delivered by Popov, which agrees with his indication "sp. n." and 2) unlike Balabayev's one, it provides more or less exact information on the locality. (sp. n.)» (лектотип) и «Erysimum samarkandicum M. Рор.» (образец из TASH); к сожалению, даты не указаны. Сбор из Фарапа пометок Попова не имеет, но нельзя исключать, что он также был известен ему до выхода публикации с описанием вида. При обозначении лектотипа предпочтение отдано образцу из Ревата, поскольку, во-первых, неопубликованный эпитет "maracandicum" свидетельствует в пользу того, что определение было сделано до выхода публикации, когда автор ещё окончательно не определился с названием, и это согласуется с пометкой «sp. n.»; во-вторых, в отличие от образца Балабаева, здесь есть б. м. точное указание на место сбора.

= Erysimum purpureum var. turkestanicum Franch., 1883, Ann. Sci. Nat. (Paris) Bot., sér. 6, 15: 231 [Miss. Capus Pl. Turk.: 20]. - Synonymised by Popov (1925: 24).

По протологу / on the protologue: "Ourmitane-Tchoukalik, alt. appr. 2200 mètres; juin, n. 144" (Franchet, 1883: 232).

Lectotypus (hic designatus): [Таджикистан, Согдийская обл. / Tajikistan, Sughd Prov.]: “OurmitaneTchoukalik, alt. appr. 2200 mètres. Juin 1881 [fl., fr.]. M. Capus, n. 144" (P [P05354372]!; isolecto - P [P05354373 \& P05354374]!).

Note 1. Out of three duplicates, the one bearing preparation of a flower and analytical drawings by Franchet is selected as the lectotype.

Note 2. One of the isolectotypes (P05354374) is supplied with the following note: "Erysimum samarkandicum M. Pop. in Sched. ad Herb. Fl. As. Med. (1925) n 91 in adn. (=E. Franchetii N. Busch et E. epikeimenum N. Busch in Fl. URSS. 8. Ms.). 1938. X. 25. Vvedensky".
Прим. 1. В качестве лектотипа обозначен образец, снабжённый препаратом цветка, а также аналитическими рисунками Франше.

Прим. 2. К одному из изолектотипов (Р05354374) подклеена заметка следующего содержания: «Erysimum samarkandicum M. Pop. in Sched. ad Herb. Fl. As. Med. (1925) n 91 in adn. (= E. Franchetii N. Busch et E. epikeimenum N. Busch in Fl. URSS. 8. Ms.). 1938. X. 25. Vvedensky».

$\equiv$ Erysimum franchetii N. Busch, 1939, Fl. URSS 8: 639, 125, "francheti". - Synonymised by Botschantzev \& Vvedensky (1955: 91).

По протологу / on the protologue: "Typus: Urmistan [Urmitan] 2200 m, Czukalan [Czukalik], leg. Franchet [Capus]; Ziaddin - Kermin 24 IV 1884 fl. fr. leg. A. Regel; in herb. Ac. Sc. URSS conservatur" (Busch, 1939: 639); “Описан из Урмитана, 2200 м, Чукалан. Тип в Ленинграде [Described from Urmitan, 2200 m, Chukalan. Type in Leningrad]" (Busch, 1939: 125).

Lectotypus (hic designatus): the same as that of E. purpureum var. turkestanicum (P05354372!); isolecto - P [P05354373 \& P05354374]!; syn - LE [LE01140658 - LE01140660]!

Polatschek (2010: 207) treated the name E. franchetii as illegitimate probably because of presence of E. samarkandicum in synonymy in the protologue of $E$. franchetii; however, from the way of citing that name, "E. samarkandicum M. Pop. in sched. herb." (Busch, 1939: 125, 639), it is unambiguously clear that it refers exclusively to the relevant determination by Popov available on one of three duplicates of Regel's gathering (LE01140660). In fact, the latter collection, in accordance with identification of another duplicate (LE01140658) by N.
А. Полячек (Polatschek, 2010: 207) считал название E. franchetii незаконным, по-видимому, основываясь на наличии в его протологе в качестве синонима E. samarkandicum, однако последнее сопровождается уточнением «in sched. herb.» и относится, таким образом, лишь к соответствующему определению Попова на одном из трёх образцов, составляющих сбор Регеля (LE01140660). В действительности растения Регеля, в соответствии с определением другого дублета (LE01140658) Н. П. Иконниковым-Га- 
P. Ikonnikov-Galitzky dated 20 III 1937, belongs to E. violascens. Hence, original material of $E$. franchetii is heterogenous and includes two species (which also agrees with hymeric character of its description) thus implying the need of disruptive typification. The choice in favour of Capus's specimen hits two targets. First, it allows keeping the traditional understanding of $E$. franchetii as a synonym of $E$. samarkandicum, a concept introduced in 1955 (and first expressed by A. I. Vvedensky in herbarium even before the publication of $E$. franchetii) and universally followed (e. g., Adylov, 1974; Yunusov, 1978; Czerepanov, 1995; Warwick et al., 2006; Polatschek, 2010; Koch et al., 2018; POWO; WFO, 2021) since then. Second, this is the way to avoid becoming E. franchetii a priority name for the species uniformly known for nearly hundred years as E. violascens, the situation inevitable in case the proposal to conserve the latter name (German, 2021 ) is not approved and $E$. franchetii is typified by Regel's syntype. The present typification excludes these undesirable consequences disturbing the nomenclatural stability and fixes the established taxonomic tradition. лицким от 20 марта 1937 г., представляют собой E. violascens. Таким образом, два сбора, составляющие первоначальный материал по E. franchetii, относятся к разным видам (это отражено и в химерном характере описания), обусловливая необходимость дизруптивной типификации. Выбор в качестве лектотипа образца Капю продиктован, во-первых, стремлением сохранить понимание данного таксона, который, начиная с момента сведения его в синонимы к E. samarkandicum в 1955 г. (а в гербарии А. И. Введенским - даже до обнародования E. franchetii), никогда иначе не понимался (Adylov, 1974; Yunusov, 1978; Czerepanov, 1995; Warwick et al., 2006; Polatschek, 2010; Koch et al., 2018; POWO; WFO, 2021; etc.), а во-вторых - намерением не допустить ситуации, когда данное название стало бы приоритетным для вида, уже почти 100 лет известного как E. violascens, что было бы неизбежным в случае непринятия предложения о консервации этого биномиала (German, 2021) и выбора в качестве лектотипа E. franchetii образца Регеля. Предложенная типификация исключает такое развитие событий и закрепляет устоявшуюся таксономическую традицию.

= Erysimum epikeimenum N. Busch, 1939, Fl. URSS 8: 637, 126. - Synonymised by Botschantzev \& Vvedensky (1955: 91).

По протологу / on the protologue: “Typus: decliv. Jugi Zeravschan, Akbi-zerkak 1800 m 9 VI 1913 fr. Michelson. Magian-Marguzar 19 VII 1912, fl. fr. imm. Preobrashensky; in herb. Ac. Sc. URSS conservatur” (Busch, 1939: 637); “Описан с южного склона Зеравшанского хребта, с перевала Акби-зеркак 1800 м и из Магиан-Маргузар [Described from southern slope of Zeravschan range, Akbi-serkak pass $1800 \mathrm{~m}$ and from Magian-Marguzar. Type in Leningrad]" (Busch, 1939: 126).

Lectotypus (hic designatus): [Таджикистан, Согдийская обл. / Tajikistan, Sughd Prov.]: “Самаркандская обл. Магиан-Маргузар. [fl., fr. immat.] 19 VI 1912. И. А. Преображенский [Samarkand Prov. Magian-Marguzar. 19 VI 1912. I. A. Preobrazhensky]” (LE [LE01140661]!; isolecto - LE [LE01140662 \& LE01140663]!; syn: “Самаркандская обл., Самаркандский уезд. Южн. скл. Зеравш. хр. Перев. Акбизеркак [Акбасергак], 6460 ф. [ff.] 9 VI 1913. А. И. Михельсон, № 2057 [Samarkand. prov., Samarkand distr. Southern slope of Zeravshan range, Akbasergak pass, 6460 ft. 9 VI 1913, A. I. Michelson 2057]" - LE [LE01140664]!).

Similarly to E. franchetii, E. epikeimenum has been "officially" synonymised with E. samarkandicum in "Flora Uzbekisanica" (Botschantzev, Vvedensky, 1955) and relevant determinations of syntypes of E. epikeimenum by A. I. Vvedensky are dated yet October 1938. Subsequently this understanding became generally followed (Adylov, 1974; Yunusov, 1978; Czerepanov, 1995; Warwick et al., 2006) until Polatschek (2010) proposed a radically new approach, viz. relegation of $E$. epikeimenum to synonymy of E. cyaneum, a viewpoint currently reflected in some online-
Как и E. franchetii, E. epikeimenum был «официально» синонимизирован с $E$. samarkandicum во «Флоре Узбекистана» (Botschantzev, Vvedensky, 1955 [а соответствующие определения А. И. Введенского датированы ещё октябрём 1938 года]), и впоследствии принимался именно в таком качестве (Adylov, 1974; Yunusov, 1978; Czerepanov, 1995; Warwick et al., 2006). А. Полячек (Polatschek, 2010) предложил новое решениерассмотрение E. epikeimenum в составе E. cyane$u m$, что отражено теперь в некоторых онлайнpecypcax (например, POWO; WFO, 2021). Mop- 
resources (e. g., POWO; WFO, 2021). Morphology of syntypes of E. epikeimenum (characteristic habit, relatively small flowers, siliques appressed to the infructescence axis and attenuated into a style several times narrower than fruit) combined with the distibution in the system of Hissar and Zeravshan ranges definitely excludes the possibility of assigning them to E. cyaneum and clearly favours the traditional approach which is unequivocally accepted herein.

Note. Recognition of A. I. Michelson's specimen as the holotype of E. epikeimenum by Polatschek (2010: 205, "typus") cannot be accepted since two gatherings were cited as type in the protologue. фология синтипов E. epikeimenum (характерный габитус растений, сравнительно мелкие цветки, прижатые к оси соцветия плоды со столбиком, в несколько раз более узким, чем стручок) вкупе с распространением в системе Гиссарского и Зеравшанского хребтов не позволяет относить их к E. cyaneum и свидетельствует в пользу традиционной точки зрения, которая здесь одназначно принята.

Прим. Образец А. И. Михельсона приведён А. Полячеком в качестве голотипа E. epikeimenum (Polatschek, 2010: 205, "typus"), однако обозначение типом двух сборов в протологе исключает возможность такой интерпретации.

= Erysimum jodonyx Botsch. et Vved., 1941, Not. Syst. Herb. Inst. Bot. Zool. Sect. Uzbek. Acad. Sci. URSS 3: 12, syn. nov.

По протологу / on the protologue: “Тypus: Яккабаг, между сел. Таш-курган и Зармас (к Кизилташу), на краснопесчаниковых холмах. 1916. V. 31 fl. et fr. imm. Попов, 1122 (in Herb. Hort. Bot. Univer. As. Med. sub n 73326 conservatur; cotypus no 73327). - Paratypus: (Горы Мальгузар). Шайбек. 1920. VI. 26 fl. et fr. imm. Балабаев, 784 (ibid., n 73332)" (Botschantzev, Vvedensky, 1941: 13).

Typus: [Узбекистан, Кашкадарьинская обл. / Uzbekistan, Kashkadarya Prov.]: “Яккабаг, между сс. Таш-Курган и Зармас [fl., fr. immat.], 31 V 1916. М. Г. Попов, № 1122 [Yakkabag, between Tash-Kurgan and Zarmas. 31 V 1916. M. G. Popov 1122] (TASH № 73326!; iso [Popov 1123] - TASH № 73327!).

Note. Ecology ("on red sand hills") mentioned in the protologue is taken from the label of isotype.

For nearly seven decades the taxonomic distinctness of E. jodonyx has not been doubted (Botschantzev, Vvedensky, 1955; Adylov, 1974; Czerepanov, 1995), until Polatschek (2010: 211) proposed synonymising it with E. cyaneum. However, this decision cannot be accepted since it has neither morphological nor geographical ground (German, 2012). At the same time, the reasons to deny the species status of E. jodonyx do indeed exist. Its evident relationship to E. samarkandicum was mentioned yet in the original description (Botschantzev, Vvedensky, 1941). The prior was said to differ from the latter in longer (3-5 vs. $1.2-2.5 \mathrm{~cm}$ long) siliques covered with exclusively 2-rayed (instead of a mixture of 2 and 3-rayed) trichomes as well as bicolor petals with violet claw and yellow limb (vs. uniformly violet throughout). As for the fruit indumentum, already in the "Flora Uzbekistanica" it has been corrected to "2-rayed with an admixture of 3-rayed trichomes" (Botschantzev, Vvedensky, 1955: 92). Noteworthy, rare 4-rayed trichomes are also present on fruits of $E$. jodonyx which agrees well with the updated description of E. samarkandicum by Polatschek (2010: 208). Regarding the distinction in the lenth of siliques mentioned in the protologue of E. jodonyx, it can only be explained
Прим. Экология - «на краснопесчаниковых холмах» указана на этикетке изотипа.

Долгое время видовая самостоятельность E. jodonyx не подвергалась сомнению (Botschantzev, Vvedensky, 1955; Adylov, 1974; Czerepanov, 1995), пока А. Полячек (Polatschek, 2010: 211) не предложил рассматривать его как синоним E. cyaneum. Данное решение, однако, не может быть принято в силу несоответствия морфологии и распространения E. jodonyx таковым E. cyaneum (German, 2012). В то же время, основания не считать обсуждаемый таксон отдельным видом действительно есть. Очевидное родство E. jodonyx с E. samarkandicum отмечалось ещё при описании первого (Botschantzev, Vvedensky, 1941), который авторы отличали от E. samarkandicum более длинными (3-5, а не 1,2-2,5 см дл.) стручками, опушенными только 2-конечными (а не 2-3-конечными) волосками, а также лепестками с фиолетовым ноготком и жёлтым отгибом (а не целиком фиолетовыми). Что касается опушения стручков, уже во «Флоpe Узбекистана» (Botschantzev, Vvedensky, 1955: 92) оно было скорректировано до «2-конечных с примесью 3-конечных» волосков. Стоит отметить, что на плодах E. jodonyx имеются также и редкие 4-конечные трихомы, что согласуется с уточнённым описанием E. samarkandicum у 
by the suggestion (confirmed by revision of relevant material) that collections of E. samarkandicum V. P. Botschantzev and A. I. Vvedensky had in their disposition were quite inadequate and represented entirely by short-fruited specimens. Subsequent accumulation of additional material enabled S. Yu. Yunusov (1978: 68) correcting this value to $1-5 \mathrm{~cm}$ long thus completely covering the parameters reported for E. jodonyx. To be noted, no correlation between the distribution of specimens and length of their fruits is observed: the type of E. jodonyx originates from the south-western part of E. samarkandicum area, the paratype was collected from its northern-eastern portion and similar plants are known from the center of the distribution area of the latter, e. g. the gathering of B. A. Fedtschenko from Archa-Maidan (№ 91, 8 VII 1913 - LE!); similarly, short-fruited specimens occur throughout the territory occupied by the species. Besides, the alledgely diagnostic difference in fruit length is sometimes covered by the variation within the same plant. For instance, siliques of the specimen of R. V. Kamelin from Mal'guzar Mts. (№ 155, 15 VII 1972 LE!), e. g. from the area of origin of the paratype of $E$. jodonyx, are 21 to $40 \mathrm{~mm}$ long while the abovementioned plant from Archa-Maidan has fruits 24 to $48 \mathrm{~mm}$ long. Finally, the distinction in petal colour also disappears completely even based on the relatively limited herbarium material. Both unicolour (violet, pale- to dirty-yellow, brownish, white) and bi- or even tricolour (violet-yellow, violet-white or violet-yellow-white, with darker proximal and lighter distal part that includes either the whole limb or just its marginal portion) petals can be observed on specimens of E. samarkandicum, i. e., the colour reported for E. jodonyx is just one of several variants of colour change under drying characteristic of E. samarkandicum. T. A. Adylov (1974: 77) suggested that E. jodonyx is a yellow-flowered species in which the violet hint of the petal claw is becoming manifested on herbarium specimens with the lapse of time. This, however, seems to be the contrary and the observed desiccation-induced chromatic change is typical for E. samarkandicum as first mentioned yet by M. A. Franchet (1883: 232): "flores purpurei, demum pallescentes vel fere lutescentes". Summing up, none of the diagnostic features of E. jodonyx enables separating it from E. samarkandicum, and relevant synonymy is therefore established here.
Полячека (Polatschek, 2010: 208). Относительно длины плодов, очевидно, противопоставление, указанное в протологе $E$. jodonyx, объясняется тем, что имевшиеся в распоряжении авторов немногочисленные сборы E. samarkandicum были представлены короткоплодными образцами. Накопление же дополнительного материала позволило уже С. Ю. Юнусову уточнить данное значение до «1-5 см дл.» (Yunusov, 1978: 68), т. е. полностью включить сюда показатели, характерные для E. jodonyx. При этом не выявляется и географической приуроченности длинноплодных образцов: тип E. jodonyx происходит из юго-западной части ареала E. samarkandicum, а паратип - из северо-восточной; такие же экземпляры известны и из центральной части, например, сбор Б. А. Федченко из уроч. Арча-Майдан (№ 91, 8 VII 1913 - LE!); при этом по всему ареалу встречаются и короткоплодные образцы. Кроме того, указанную разницу в длине плода иногда перекрывает варьирование в пределах одного растения. Например, образец Р. В. Камелина с гор Мальгузар (№ 155, 15 VII 1972 - LE!), откуда собран паратип $E$. jodonyx, имеет стручки от 21 до 40 мм дл., а упомянутое выше растение из Арча-Майдана - от 24 до 48 мм. Наконец, разница в цвете лепестков также полностью стирается даже на сравнительно небольшом материале. На гербарных образцах E. samarkandicum встречаются как одноцветные (фиолетовые, бледно- или грязновато-жёлтые, коричневатые, белые), так и дву- или даже трёхцветные (фиолетово-жёлтые, фиолетово-белые или фиолетово-жёлто-белые, с более тёмной проксимальной и более светлой дистальной частью, включающей весь отгиб или его краевую часть) цветки, то есть окраска, указанная для E. jodonyx, является одним из вариантов, проявляющихся при высушивании растений E. samarkandicum. Т. А. Адылов (Adylov, 1974: $77)$ предполагал, что E. jodonyx является жёлтоцветковым видом, а фиолетовый оттенок ноготка появляется на гербарных образцах со временем. Очевидно, что изменение цвета носит здесь обратный характер, типичный для E. samarkandicum и отмеченный ещё М. А. Франше (Franchet, 1883: 232): «flores purpurei, demum pallescentes vel fere lutescentes». Таким образом, ни один из диагностических признаков E. jodonyx не позволяет отделять его от E. samarkandicum, в связи с чем устанавливается соответствующая синонимика. 
Erysimum violascens M. Pop., 1925, Bull. Univ. As. Centr. 9, Suppl. (Sched. Herb. Fl. As. Med., 4): 24, nom. prop. cons. (German, 2021). 三 Dichroanthus violascens M. Pop., 1925, Bull. Univ. As. Centr. 9, Suppl. (Sched. Herb. Fl. As. Med., 4): 25, in obs., nom. altern.

По протологу / on the protologue: "Prov. Samarkand; distr. Chodshent. Montes Mogol-tau. I. Ad declivia saxosa in valle Utsch-bach. 1924. V. 6 fl. II. Ad declivia saxosa in cacumine Bars. 1923. VI. 18 fr. submat. Leg. Popov et Vvedensky. ... Hors des monts Mogol-tau, ... dans les montagnes sèches et basses de Zerabulak près de la ville Katta-Kurgan dans l'arrondissement de Samarkand, sur le cours inférieur du fleuve Zeravschan (1921. VI. 7 fr. $n^{\circ} n^{\circ}$ 269, 277, 278, 279, 281!!)” (Popov, 1925: 25).

Lectotypus (Gureyeva et al., 2012: 14): [Таджикистан, Согдийская обл. / Tajikistan, Sughd Prov.]: "Prov. Samarkand; distr. Chodshent. Montes Mogol-tau. Ad declivia saxosa in valle Utsch-bach, 6 V 1924, fl. Popov et Vvedensky" [Herb. Fl. As. Med., exs. № 91] (TASH № 9422!; isolecto - B [B 100263584 \& B 10 0263585]!, BP № 295138!, BR!, BRNU № 131332!, C!, E [E00231860]!, G [G00374261]!, GH, K [K000693844 \& K000693845]!, KW № 095335!, LE [LE01140652 \& LE01140653]!, MHA!, MW [MW0592635]!, NY [NY 01163553], P [P02272774]!, S № S-G-10205, TBI!, TK!, W № 1927-0011442!; syn: M. G. Popov \& A. I. Vvedensky, 18 VI 1923: № 134 - GB [GB-0195154]! \& MW [MW0595624]!, № 124 - LE [LE01140654]!, №№ 123, 125, 127, 128 - TASH [s. n, s. n., №№ 9423, 73313]!; Popov, 7 VI 1921: № 279 - LE [LE01140655]!, №№ 269, 277, 278, 281 - TASH [№ 9424, s. n., №№ 73312, 9425]!).

Распространение / distribution: Таджикистан, Узбекистан / Tajikistan, Uzbekistan.

Note 1. Lectotype and isolectotypes are exsiccate specimens represented by plants with flowers. Except for the duplicates from K (K000693845), $\mathrm{P}$ and $\mathrm{W}$, each exsiccate sheet also includes either a part of infructescence or several separate friuts placed in an envelope. These fragments belong to the gathering of M. G. Popov and A. I. Vvedensky made 18 June 1923 and are syntypes. The rest of this gathering comprises several (I managed to find seven) specimens all of which include intact (complete) plants; they were not issued as exsiccata and available now only in GB, MW, LE and TASH.

Note 2. Unfortunately, this well-established, universally accepted name unambiguously and persistently used for almost a century turned out to be illegitimate on account of its superfluity to $E$. cyaneum, though not being homotypic with the latter. Having in mind obvious negative consequences of exclusion of the binomial E. violascens from use, a conservation proposal has been recently prepared (German, 2021). In accordance with the ICN Recommendation 14A (Turland et al., 2018), existing usage of the name is kept here.
Прим. 1. Лектотип и изолектитипы - эксикатные образцы, представленные растениями в фазе цветения. За исключением дублетов из $\mathrm{K}$ (K000693845), Р и W, эксикатные листы снабжены также пакетиком с частью соплодия или несколькими отдельными стручками; эти фрагменты относятся к сбору М. Г. Попова и А. И. Введенского от 18 июня 1923 г. и являются синтипами. Остальная часть данного сбора представлена немногочисленными (было обнаружено семь) образцами, составленными целыми растениями, не изданными в виде эксикат и имеющимися только в GB, MW, LE и TASH.

Прим. 2. К сожалению, данное название, всегда употреблявшееся в строго определённом смысле и принятое во всех соответствующих работах, оказалось незаконным, будучи излишним для E. cyaneum, хотя и не гомотипным с ним. Ввиду очевидной нежелательности вывода биномиала E. violascens из использования, было внесено предложение о его консервации (German, 2021). В соответствии с рекомендацией $14 \mathrm{~A}$ МКН (Turland et al., 2018), здесь сохранено традиционное понимание названия.

= Erysimum nuratense M. Pop. ex Botsch. et Vved., 1948, Not. Syst. Herb. Inst. Bot. Zool. Acad. Sci. Uzbekistan. 12: 6. - Synonymised by Polatschek (2010: 216).

По протологу / on the protologue: “Тypus: Нуратинские горы. Ак-тау. Местность Янг-оглы, у пос. Лянгар. 1941. V. 19-21 fl. et fr. submat. Закиров и Ниязов (in Herb. Hort. Bot. Univer. As. Med. conservatur)" (Botschantzev, Vvedensky, 1948: 7).

Typus: [Узбекистан, Навоийская обл. / Uzbekistan, Navoiy Prov.]: "Нуратинские горы. Ак-тау. Местность Янг-оглы, у пос. Лянгар. 19-21 V 1941. [fl., fr. submat.] К. З. Закиров и Ниязов [Nuratau Mts. Ak-tau. Yang-ogly, near Lyangar. 19-21 V 1941. K. Z. Zakirov \& Niyazov]” (TASH!). 
Erysimum violascens varies with respect to the direction of siliques that are usually divaricateascending to less often ascending or horizontally reflexed; an angle with the inflorescence axis normally ranges within (30)45-70(90) ${ }^{\circ}$. Plants from Nuratau Mts. (north-western distribution limit of the species) are somewhat special in having typically ascending to rarely divaricate-ascending and never horizontal fruits forming an angle with the axis (15)20-40(60) $)^{\circ}$, and this is the only character which seems to separate $E$. nuratense from $E$. violascens. Other features such as smaller flowers (10-11 vs. 13-17 mm long), orientation of fruits towards the axis (appessed vs. divaricate), width of pedicel in relation to silique (subequaling vs. smaller), fruit size $(2.5-3 \mathrm{~cm} \times 1 \mathrm{~mm}$ vs. $1.5-7 \mathrm{~cm} \times 1.5 \mathrm{~mm})$ (Botschantzev, Vvedensky, 1948, 1955; Adylov, 1974; German, 2012) reported as discriminating the prior species from the latter, appear not working based on the material consulted. Flower size of $E$. nuratense falls within the range of $E$. violascens and fit its lower limit found in plants, especially deflorating, from other parts of the distribution area of the species. Orientation of siliques (only some are indeed appressed to rachis while others are ascending and forming an angle to $20^{\circ}$ with it) and their dimensions mentioned based on the holotype (Botschantzev, Vvedensky, 1948) refer to not fully ripe fruits. Having in mind the considerable overlap in the above-mentioned degree of fruit deflection (e. g., specimens with siliques ascending at just $30^{\circ}$ are known from Mogol-Tau - the easternmost limit of the range of E. violascens) and lack of differences in any other morphological character between the two taxa in question, I find assigning E. nuratense to synonymy of $E$. violascens proposed by Polatschek (2010) fully justified.
Erysimum violascens варьирует по степени отклонённости стручков от оси соцветия от косо вверх стоящих до (чаще всего) значительно или даже горизонтально отклонённых; угол между плодом и осью соцетия составляет (30)45-70(90) ${ }^{\circ}$. Растения с хр. Нуратау (сев.-зап. предел распространения вида) выделяются в целом менее (под (15)20-40(60) ${ }^{\circ}$ ) отклюнёнными плодами, и это - единственный признак, позволяющий отличать E. nuratense от E. violascens. Bce прочие характеристики, приводившиеся как диагностические [более мелкие (10-11, а не 13-17 мм дл.) лепестки, прижатые к оси соцветия (а не отклонённые от неё) плоды 2,5-3 cм $\times$ 1 мм (а не 1,5-7 см × 1,5 мм), цветоножки, примерно равные по толщине стручкам (а не более тонкие)] (Botschantzev, Vvedensky, 1948, 1955; Adylov, 1974; German, 2012), на изученном материале совершенно не выдерживаются. Так, размер цветков E. nuratense представляет нижний предел значений, характерных для E. violascens из разных частей ареала, особенно для отцветающих растений. Что касается плодов, их размеры, а также прижатость к оси соцветия, указанные в первоисточнике (Botschantzev, Vvedensky, 1948), относятся к образцу с не вполне зрелыми стручками (при этом часть их отклонена до $20^{\circ}$ ). С учётом значительного перекрывания градуса отклонённости плодов (и того факта, что, например, растения со стручками, расположенными под углом всего $30^{\circ}$ к оси соцветия, встречаются и на хр. Могол-Тау, т. е. на восточной границе apeала E. violascens) и фактического отсутствия иных признаков, разделяющих обсуждаемые таксоны, предложенная А. Полячеком синонимизация E. nuratense представляется верной.

\section{Благодарности / Acknowledgements}

Curators of all visited herbaria and respective departments are cordially thanked for providing the opportunity of working with collections. Kind help of Polina Vasilievna Veselova, Georgy Anatolievich Lazkov, Denis Germanovich Melnikov, Ihsan Ali Al-Shehbaz and Komiljon Sharobitdinovich Tojibaev during the visits to Almaty, Bishkek, Paris, St. Petersburg and Tashkent, respectively, as well as the nomenclatural advice of Alexander Nikolaevich Sennikov are also highly appreciated. The study was supported by the Ministry of Science and Higher Education of Russian Federation (project No. FZMW-2020-0003). / Выражаю искреннюю благодарность кураторам всех посещённых гербариев и их отделов за предоставленную возможность работы с материалом; Полине Васильевне Веселовой, Георгию Анатольевичу Лазькову, Денису Германовичу Мельникову, Исану Али Аль-Шебазу и Комилжону Шаробитдиновичу Тожибаеву - за помощь во время визитов, соответственно, в Алматы, Бишкек, Париж, СанктПетербург и Ташкент; Александру Николаевичу Сенникову - за ценные советы по вопросам номенклатуры. Работа выполнена в рамках государственного задания Министерства науки и высшего образования Российской Федерации (тема № FZMW-2020-0003). 


\section{ЛИТЕРАТУРA / REFERENCES}

Abdelaziz M., Muñoz-Pajares A. J., Lorite J., Herrador M. B., Perfectti F., Gómez J. M. 2014. Phylogenetic relationships of Erysimum (Brassicaceae) from the Baetic Mountains (SE Iberian Peninsula). Anal. Jard. Bot. Madrid 71(1): e005. DOI: 10.3989/ajbm.2377

Abidkulova K. T., Mukhitdinov N. M., Ivashchenko A. A., Ametov A., Serbayeva A. D. 2017. Morphological characteristics of a rare endemic species Erysimum croceum M. Pop. (Brassicaceae) from Trans-Ili Alatau, Kazakhstan. Modern Phytomorph. 11: 131-138. DOI: 10.5281/zenodo.1133848

Adylov T. A. 1974. Erysimum L. In: Conspectus florae Asiae Mediae. A. I. Vvedensky (Ed.). Vol. 4. Tashkent: Editio Academiae Scientarum UzSSR. Рp. 69-78. [In Russian] (Адылов T. A. Erysimum L. - Желтушник // Определитель растений Средней Азии / Под ред. А. И. Введенского. Т. 4. Ташкент: Изд-во ФАН УзССР, 1974. С. 69-78).

Baitulin I. O., Ogar N. P., Nesterova S. G., Inelova Z. A. 2017. Flora Ileyskogo Alatau [Flora of Trans-Ili Alatau]. Almaty: Kazakh University. 196 pp. [In Russian] (Байтулин И. О., Огарь Н. П., Нестерова С. Г., Инелова З. А. Флора Илейского Алатау. Алматы: Қазақ университеті, 2017. 196 с.).

Bajtenov M. S. 1982. Plantae endemicae alpinis montes Tian-Schan borealis. Bot. Mater. Gerb. Inst. Bot. Acad. Nauk Kazahhsk. SSR [Not. Syst. Herb. Inst. Bot. Acad. Sci. Kazachst.] 12: 3-8. [In Russian] (Байтенов М. С. Эндемичные растения высокогорий Северного Тянь-Шаня // Бот. мат. Герб. Ин-та бот. АН КазССР, 1982. Т. 12. С. $3-8)$.

Botschantzev V. P., Vvedensky A. I. 1941. Species plantarum novae. Bot. Mater. Gerb. Bot. Inst. Uzbekistansk. Fil. Akad. Nauk SSSR [Not. Syst. Herb. Inst. Bot. Sect. Uzb. Acad. Sci. URSS] 3: 3-20. (Бочанцев В. П., Введенский A. И. Новые виды растений // Бот. мат. Герб. Бот. ин-та Узб. фил. АН СССР, 1941. Т. 3. С. 3-20).

Botschantzev V. P., Vvedensky A. I. 1948. Cruciferae novae ex Asia Media. Bot. Mater. Gerb. Inst. Bot. i Zool. Akad. Nauk UzSSR [Not. Syst. Herb. Inst. Bot. Zool. Acad. Sci. Uzbekistan] 12: 3-12. [In Russian] (Бочанцев В. П., Введенский $\boldsymbol{A}$. И. Новые крестоцветные из Средней Азии // Бот. мат. Герб. Ин-та бот. и зоол. АН УзССР, 1948. T. 12. C. 3-12).

Botschantzev V. P., Vvedensky A. I. 1955. Cruciferae. In: Flora Uzbekistanica. E. P. Korovin (Ed.). Vol. 3. Tashkent: Editio Academiae Scientarum UzSSR. Pp. 65-221. [In Russian] (Бочанцев В. П., Введенский А. И. Сruсіfеrae - Крестоцветные // Флора Узбекистана / Под ред. Е. П. Коровина. Т. 3. Ташкент: Изд-во АН Узбекской ССР, 1955. C. 65-221).

Busch N. A. 1939. Erysimum (Tourn.) L. In: Flora URSS [Flora of USSR]. V. L. Komarov (Ed.). Vol. 8. Moscow \& Leningrad: Editio Academiae Scientarum URSS. Pp. 92-127, 637-639. [In Russian] (Буш Н. А. Желтушник - Erysimum (Tourn.) L. // Флора СССР / Под ред. В. Л. Комарова. Т. 8. М.-Л.: Изд-во АН СССР. С. 92-127, 637-639).

Czerepanov S. K. 1995. Vascular plants of Russia and adjacent states (the former USSR). Cambridge: Cambridge University Press. X +519 pp.

Franchet M. A. 1883. Mission Capus. Plantes du Turkestan. Ann. Sci. Nat. Bot., sér. 6, 15: 214-268.

Gaziev A. 2016. Image of Erysimum cyaneum Popov. In: Plantarium. Plants and lichens of Russia and neighboring countries: open online galleries and plant identification guide. 2007-2021. URL: https://www.plantarium.ru/lang/ en/page/image/id/418094.html

German D. A. 2012. Erysimum kamelinii, a new species from the Middle Asia and further additions to Polatschek's revision of the genus Erysimum (Cruciferae), part 1. Ann. Naturhist. Mus. Wien, ser. B 113: 266-272. URL: https:// www.jstor.org/stable/41767517

German D. A. 2014. Notes on taxonomy of Erysimum (Erysimeae, Cruciferae) of Russia and adjacent states. I. Erysimum collinum and Erysimum hajastanicum. Turczaninowia 17, 1: 10-32. [In Russian and English] (Герман Д. A. Заметки по систематике рода Erysimum (Erysimeae, Cruciferae) России и сопредельных стран. I. Erysimum collinum и Erysimum hajastanicum // Turczaninowia, 2014. Т. 17, № 1. С. 10-32). DOI: 10.14258/turczaninowia.17.1.3

German D. A. 2021. (2817) Proposal to conserve the name Erysimum violascens (Cruciferae). Taxon 71(3): 678679. DOI: $10.1002 / \operatorname{tax} .12514$

German D. A., Veselova P. V. 2011. Type specimens of names of Brassicaceae (Cruciferae) taxa deposited in the Herbarium of the Institute of Botany and Phytointroduction of Kazakhstan (AA). Bot. Zhurn. 96(10): 1378-1388. [In Russian] (Герман Д. А., Веселова П. В. Типовые образцы таксонов семейства Brassicaceae (Cruciferae), хранящиеся в Гербарии Института ботаники и фитоинтродукции Казахстана (АА) // Бот. журн., 2011. Т. 96 , № 10. C. 1378-1388).

Goloskokov V. P. 1963. Herbarium typorum plantarum Kasachstanicae. Bot. Mater. Gerb. Inst. Bot. Acad. Nauk Kaz. SSR [Not. Syst. Herb. Inst. Bot. Acad. Sci. Kazachst.] 1: 4-67. [In Russian] (Голоскоков В. П. Гербарий типов растений Казахстана // Бот. мат. Герб. Ин-та бот. АН КазССР, 1963. Т. 1. С. 4-67).

Gureyeva I. I., Balashova V. F., German D. A., Ebel A. L. 2012. Type specimens of Brassicaceae Burnett in the Krylov Herbarium (TK). Animadv. Syst. Herb. Kryl. Univ. Tomsk. 106: 3-23. [In Russian] (Гуреева И. И., Балашова В. Ф., Герман Д. А., Эбель А. Л. Типовые образцы Brassicaceae Burnett в Гербарии им. П. Н. Крылова (ТК) // Сист. зам. Герб. им. П. Н. Крылова, 2012. Т. 106. С. 3-23). 
IPNI [2021]. The International Plant Names Index. URL: http://www.ipni.org (Accessed 2 August 2021).

Kitagawa M. 1933. On the vegetation of Isl. Mang-tao, South Manchuria. J. Jap. Bot. 9(2): 103-120.

Koch M. A., German D. A., Kiefer M., Franzke A. 2018. Database taxonomics as key to modern plant biology. Trends Plant Sci. 23(1): 4-6. DOI: 10.1016/j.tplants.2017.10.005

Kokoreva I. I., Lysenko V. V., Otradnykh I. G., S'edina I. A. 2010. Ecological and morphological features of the rare species Erysimum croceum M. Pop. Izvestiya NAN RK. Seriya boil. [Proc. Natl Acad. Sci. Kazakhstan. Ser. Biol.] 2010, 1: 40-45. [In Russian] (Кокорева И. И., Лысенко В. В., Отрадных И. Г., Съедина И. А. Эколого-морфологические особенности редкого вида Erysimum сroceum М. Рор. // Известия НАН РК. Сер. биол., 2010. Т. 2010 г., № 1. С. 40-45).

Komarov V. L. 1896. Materials to the flora of Turkestan mountains. Basin of the River Zeravshan. Trudy Imp. S.Peterb. Obshchestva Estestvoisp. Otd. Bot. [Trav. Soc. Nat. Pétersb. Sect. Bot.] 26, 3: 31-162. [In Russian] (Koмapoв $\boldsymbol{B}$. Л. Материалы по флоре Туркестанского нагорья. Бассейн Зеравшана // Труды Имп. СПб. об-ва естествоисп. Отд. бот., 1896. Т. 26, № 3. С. 31-162).

Lazkov G. A., Sultanova B. A. 2014. Kadastr flory Kyrgyzstana. Sosudistyye rasteniya [Checklist of vascular plants of Kyrgyzstan]. Bishkek: National Academy of Sciences of Kyrgyz Republic. 126 pp. [In Russian] (Лазьков $\boldsymbol{\Gamma}$. A., Султанова Б. A. Кадастр флоры Кыргызстана. Сосудистые растения. Бишкек: НАН КР, 2014.126 с.).

Moazzeni H., Zarre Sh., Assadi M., Joharchi M. R., German D. A. 2014a. Erysimum hezarense, a new species and Rhammatophyllum gaudanense, a new record of Brassicaceae from Iran. Phytotaxa 175(5): 241-248. DOI: 10.11646/phytotaxa.175.5.1

Moazzeni H., Zarre Sh., Pfeil B. E., Bertrand Y. J. K., German D. A., Al-Shehbaz I. A., Mummenhoff K., Oxelman B. 2014b. Phylogenetic perspectives on diversification, biogeography and character evolution in the species-rich genus Erysimum (Erysimeae; Brassicaceae) based on a densely sampled ITS approach. Bot. J. Linn. Soc. 175(4): 497-522. DOI: $10.1111 /$ boj.12184

Polatschek A. 2010. Revision der Gattung Erysimum (Cruciferae): Teil 1: Russland, die Nachfolgestaaten der USSR (excl. Georgien, Armenien, Azerbaidzan), China, Indien, Pakistan, Japan und Korea. Ann. Naturhist. Mus. Wien, ser. B 111: 181-275. URL: https://www.jstor.org/stable/41767461

Polatschek A. 2011. Revision der Gattung Erysimum (Cruciferae), Teil 2: Georgien, Armenien, Azerbaidzan, Türkei, Syrien, Libanon, Israel, Jordanien, Irak, Iran, Afghanistan. Ann. Naturhist. Mus. Wien, ser. B 112: 369-497. URL: https://www.jstor.org/stable/41767489

Popov M. G. 1924. Cruciferae. In: Opredelitel rasteniy okrestnostey Tashkenta [Key Pl. Envir. Tashkent]. M. G. Popov (Ed.). Tashkent: Botanical Institute of the Middle Asian State University. Pp. 137-160. [In Russian] (IIonoв M. $\boldsymbol{\Gamma}$. Cruciferae. Крестоцветные // Опред. раст. окр. Ташкента / Под ред. М. Г. Попова. Ташкент: Бот. ин-т Средне-Азиатск. гос. ун-та, 1924. С. 137-160).

Popov M. G. 1925. 91. Erysimum violascens M. Pop. sp. n. Byull. Sredne-Aziatsk. Gosud. Univ. [Bull. Univ. As. Centr.] 9, Suppl. (Sched. Herb. Fl. As. Med., 4): 24-25. (Попов М. Г. 91. Erysimum violascens М. Рор. sp. n. // Бюл. Средне-Азиатск. гос. ун-та, 1925. Вып. 9, Прил. (Sched. Herb. Fl. As. Med., 4). С. 24-25).

Popov M. G. 1935. Plantae novae vel criticae in montibus Alatau transiliensis (Tianschan orientalis), prope opp. Alma-Ata collectae. Byull. Moskovsk. Obshch. Isp. Prir., Otd. Biol. [Bull. Soc. Nat. Moscou. Sect. Biol.], n. s. 44(3): 125-131. [In Russian] (Попов М. Г. Новые или критические растения, собранные в хребте Заилийском Алатау в окр. гор. Алма-Ата // Бюл. МОИП. Отд. биол., нов. сер., 1935. Т. 44, № 3. С. 125-131).

POWO [2021]. Plants of the World online. URL: http://www.plantsoftheworldonline.org/ (Accessed 23 July 2021).

Roldugin I. I. 2014. Wallflower orange. Erysimum croceum M. Pop. In: The Red Data Book of Kazakhstan. I. O. Baytulin (Ed.). Vol. 2. Pt. 1. Plants. Astana: ArtPrintXXI. Pp. 190-191. [In Russian, Kazakh, English] (Ролдугин И. И. Желтушник оранжевый. Erysimuт сroceum М. Рор. // Красная книга Казахстана. Т. 2. Ч. 1. Растения. Астана: ArtPrintXXI, 2014. C. 190-191).

Shevchenko D. A. 1955. Erysimum L. In: Flora Kirgizskǒ SSR [Flora of Kirghiz SSR]. A. I. Vvedensky (Ed.).Vol. 6. Frunze: Publishers of Academy of Sciences of Kirghiz SSR. Pp. 169-175, 285. [In Russian] (Шевченко Д. А. Erysimum L. - Желтушник // Флора Киргизской ССР / Под ред. А. И. Введенского. Т. 6. Фрунзе: Изд-во АН Киргизской ССР, 1955. С. 169-175, 285).

Tolmatchew A. 1930. Über die systematische Stellung von Hesperis Pallasii. Nyt Mag. Naturvidensk. 68: 167-170.

Turland N. J., Wiersema J. H., Barrie F. R., Greuter W., Hawksworth D. L., Herendeen P. S., Knapp S., Kusber W.-H., Li D.-Z., Marhold K., May T. W., McNeill J., Monro A. M., Prado J., Price M. J., Smith G. F. 2018. International Code of Nomenclature for algae, fungi, and plants (Shenzhen Code) adopted by the Nineteenth International Botanical Congress Shenzhen, China, July 2017. Glashütten: Koeltz Scientific Books. XXXVIII + 254 pp. [Regnum Vegetabile, Vol. 159].

Warwick S. I., Francis A., Al-Shehbaz I. A. 2006. Brassicaceae: Species checklist and database on CD-Rom. Plant Syst. Evol. 259(2-4): 249-258. DOI: 10.1007/s00606-006-0422-0

Ya J. D., Cai J., Zhang Q. R. 2018. Two genera and five species newly recorded in China. Turkish J. Bot. 42(2): 239-245. DOI: $10.3906 /$ bot-1705-36 
Yunusov S. Yu. 1978. Erysimum L. In: Flora Tajikskǒ̆ SSR [Flora of Tajik SSR]. P. N. Ovczinnikov (Ed.). Vol. 5. Leningrad: Nauka. Pp. 60-69. [In Russian] (Юнусов С. Ю. Желтушник - Erysimum L. // Флора Таджикской ССР / Под ред. П. Н. Овчинникова. Т. 5. Л.: Наука, 1978. С. 60-69).

WFO [2021]. World Flora Online. URL: http://www.worldfloraonline.org/ (Accessed 24 July 2021). 